\title{
UJI RESISTENSI BAKTERI Pseudomonas sp YANG DIISOLASI DARI PLAK GIGI TERHADAP MERKURI DAN ANTIBIOTIK AMOKSISILIN
}

\author{
${ }^{1}$ Wulan Palilingan \\ ${ }^{2}$ Billy J. Kepel \\ ${ }^{2}$ Fatimawali \\ ${ }^{1}$ Kandidat Skripsi Fakultas Kedokteran Universitas Sam Ratulangi Manado \\ ${ }^{2}$ Bagian Kimia Fakultas Kedokteran Universitas Sam Ratulangi Manado \\ Email: wpalilingan_11_246@yahoo.com
}

\begin{abstract}
Mercury is the only metal in liquid form at room temperature. Dental fillings with amalgam is an example of the use of mercury in the medical field, however, it may cause serious diseases. Other attempt to reduce the toxicity of mercury is by using mercury resistance bacteria. If this bacteria is resistant to antibiotic then it may cause negative effects. This study aimed to determine the resistance of Pseudomonas $s p$ isolated from patients' dental plaques with amalgam fillings to mercury and amoxicillin. This was a descriptive exploratory study. Samples were Pseudomonas sp bacteria, mercury, and antibiotics that were available in the Laboratory of Pharmaceutical Microbiology. The results showed that Pseudomonas sp grew on Luria Bertani Media with $\mathrm{HgCl}_{2}$ concentration of 10 ppm, 20 ppm, 40 ppm but not with $\mathrm{HgCl}_{2}$ concentration of $80 \mathrm{ppm}$. During 3 repetitions of antibiotics it was found that diameters of inhibitor zones were $<12 \mathrm{~mm}$. Conclusion: Pseudomonas sp bacteria was resistant to mercury and amoxicillin.
\end{abstract}

Keywords: pseudomonas $s p$, resistant, mercury, amoxicillin

\begin{abstract}
Abstrak: Merkuri merupakan satu-satunya logam yang berwujud cair pada suhu kamar. Amalgam yang digunakan pada penambalan gigi merupakan salah satu contoh pemakaian merkuri dalam bidang kedokteran namun dapat memicu penyakit yang cukup serius bagi kesehatan. Salah satu usaha untuk menurunkan daya toksik merkuri dapat dilakukan dengan menggunakan bakteri resisten merkuri. Bila bakteri ini juga memiliki senyawa yang resisten terhadap antibiotik maka akan memberi dampak negatif. Penelitian ini bertujuan untuk menguji resistensi Pseudomonas sp yang diisolasi dari plak gigi pasien dengan tambatan amalgam terhadap merkuri dan antibiotik amoksisilin. Penelitian ini menggunakan metode deskriptif eksploratif dengan sampel bakteri Pseudomonas sp, merkuri dan antibiotik yang sudah tersedia di Laboratorium Mikrobiologi Farmasi. Hasil penelitian memperlihatkan bahwa Pseudomonas sp bertumbuh pada media Luria Bertani konsentrasi $\mathrm{HgCl}_{2} 10$ ppm, 20 ppm, 40 ppm dan dalam 3 kali pengulangan pemberian antibiotik didapatkan diameter zona hambat $<12 \mathrm{~mm}$. Simpulan: Bakteri Pseudomonas sp resisten terhadap merkuri dan antibiotik amoksisilin.
\end{abstract}

Kata kunci: pseudomonas sp, resisten, merkuri, amoksisilin

Merkuri sering disebut air raksa merupakan satu-satunya logam yang berwujud cair pada suhu kamar. ${ }^{1}$ Logam murninya berwarna keperakan, berupa cairan tak berbau, dan mengkilap. ${ }^{2}$ Merkuri sudah lama dikenal oleh manusia sehingga penggunaannya sudah cukup luas. Walaupun memiliki toksisitas sangat tinggi terhadap tubuh manusia, dalam bidang lain merkuri termasuk material yang penting., 
Amalgam yang digunakan pada penambalan gigi merupakan salah satu contoh pemakaian merkuri dalam bidang kedokteran. Sampai sekarang amalgam masih digunakan oleh dokter gigi karena merupakan bahan tambalan yang kuat, tahan lama, dan harganya murah. Namun seiring berjalannya waktu, berbagai penelitian telah mengindikasikan bahwa kandungan merkuri dalam amalgam dapat memicu penyakit yang cukup serius bagi kesehatan manusia.,

Semua komponen merkuri baik dalam bentuk metil dan bentuk alkil yang masuk ke dalam tubuh manusia secara terus menerus akan menyebabkan kerusakan permanen pada otak, hati, dan ginjal. Ion merkuri menyebabkan pengaruh toksik karena terjadinya proses presipitasi protein menghambat aktivitas enzim dan bertindak sebagai bahan yang korosif. ${ }^{5}$

Salah satu usaha untuk menurunkan daya toksik merkuri dapat dilakukan dengan menggunakan mikroorganisme resisten merkuri, misalnya bakteri resisten merkuri. Menurut Silver dan Phung, penurunan daya toksik merkuri terjadi oleh bakteri ini karena memiliki gen yang resisten, yaitu mer operon. Dengan adanya gen mer operon ini, kelompok bakteri ini mampu untuk mereduksi ion $\mathrm{Hg}^{2+}$ menjadi $\mathrm{Hg}^{0}$ yang sebelumnya bersifat toksik menjadi kurang toksik. ${ }^{6}$

Penelitian dari Ali dan Rehman ${ }^{7}$ mengatakan bahwa Pseudomonas sp merupakan salah satu bakteri yang telah diketahui dapat menjadi resisten terhadap merkuri. Bila mikroorganisme ini juga memiliki suatu senyawa yang resisten terhadap antibiotik maka organisme yang terinfeksi memiliki dampak negatif bagi kesehatan manusia itu sendiri, yaitu akan terjadi gangguan kesehatan dikarenakan kegagalan pengobatan akibat keberadaan bakteri resisten merkuri yang juga resisten terhadap antibiotik. $^{8}$

Pada umumnya resistensi yang dialami bakteri dikendalikan oleh plasmid bakteri itu sendiri. Plasmid merupakan suatu elemen genetik (DNA-Plasmid) yang terpisah dari DNA kromosomal. Plasmid mengandung faktor $\mathrm{R}$ yang dapat ditularkan ke bakteri lainnya. Faktor R ini terdiri dari dua unit, yaitu unit-r dan segmen RTF (Resistance Transfer Factor). Unir-r membawa sifat resistensi terhadap satu antibiotik maka berbagai unit-r yang terdapat pada faktor R akan membawa sifat resistensi terhadap berbagai antibiotik sekaligus. RTF bertugas memindahkan unit-r tersebut sehingga sifat resistensi dapat ditularkan ke bakteri lain. ${ }^{9}$

Di Indonesia, amoksisisilin termasuk salah satu antibiotika yang banyak diresepkan. Bahkan orang awam sering kali ditemukan membeli obat ini secara bebas tanpa resep dokter. ${ }^{10}$ Penggunaan antibiotik yang tidak rasional menyebabkan peningkatan bakteri yang resisten. ${ }^{11}$ Amoksisilin merupakan antibiotika golongan penisilin dengan spektrum antimikroba yang luas serta sensitif terhadap kuman gram positif dan gram negatif. $^{12}$

Tujuan penelitian ini ialah untuk menguji resistensi Pseudomonas sp. yang diisolasi dari plak gigi pasien dengan tambatan amalgam terhadap merkuri dan antibiotik Amoksisilin.

\section{METODE PENELITIAN}

Penelitian ini dilakukan pada bulan November-Desember $2014 \quad$ di Laboratorium Mikrobiologi Farmasi, Program Studi Farmasi, Fakultas MIPA Universitas Sam Ratulangi dengan menggunakan metode deskriptif eksploratif. Populasi penelitian ini ialah semua bakteri yang tumbuh pada plak gigi pasien dengan tumpatan amalgam. Sampel yang diambil ialah bakteri Pseudomonas sp .yang tumbuh pada media Luria Bertani (LB) broth.

Pengambilan sampel yaitu bakteri Pseudomonas sp yang sudah diisolasi dari plak gigi yang ada di Laboratorium Mikrobiologi Farmasi, Program Studi Farmasi, Fakultas MIPA Universitas Sam Ratulangi. Sampel diperiksa di Laboratorium Mikrobiologi Farmasi, Program Studi Farmasi, Fakultas MIPA Universitas Sam Ratulangi untuk dikultur 
dan diuji resistensi merkuri dan resistensi antibiotik amoksisilin.

\section{Uji resistensi merkuri}

Koloni bakteri Pseudomonas sp ditumbuhkan pada media LB broth dengan menggunakan jarum ose yang sudah mengandung merkuri, kemudian dipindahkan pada media agar miring dengan menggunakan jarum ose sebagai kultur sediaan (Antibiotik dan resisten merkuri) dan diinkubasi pada suhu $37^{\circ} \mathrm{C}$ selama 24 jam, selanjutnya disimpan pada suhu $4^{0} \mathrm{C}$, kemudian dilakukan kembali inokulasi kultur bakteri Pseudomonas sp dalam media LB broth yang mengandung $\mathrm{HgCl}_{2}$ dalam beberapa konsentrasi yang berbeda yaitu $10 \rho \rho m, 20 \rho \rho \mathrm{m}, 40 \rho \rho \mathrm{m}$ dan 80 $\rho \rho m$. Diamati jumlah koloni yang tumbuh.

\section{Uji resistensi Antibiotik}

Uji resistensi antibiotik dilakukan dengan menginokulasi bakteri resistensi merkuri pada media LB padat. Kertas disk antibiotik dengan konsentrasi $25 \mu \mathrm{g}$ antibiotik diletakkan menggunakan pinset steril pada permukaan media LB padat yang sudah diinokulasikan bakteri, kertas disk diatur jaraknya agar tidak terlalu rapat lalu diinkubasi selama 24 jam dalam antibiotik. Setelah itu diamati perubahan yang terjadi dan diukur zona beningnya dengan menggunakan mistar berskala.

\section{HASIL PENELITIAN}

Tabel 1. Uji Resistensi Merkuri

\begin{tabular}{ccc}
\hline $\begin{array}{c}\text { Media Luria } \\
\text { Bertani (LB) } \\
\text { Broth }\end{array}$ & Pertumbuhan & Keterangan \\
\hline $10 \rho \rho \mathrm{m}$ & + & Banyak \\
$20 \rho \rho \mathrm{m}$ & + & Sedang \\
$40 \rho \rho \mathrm{m}$ & + & Sedikit \\
$80 \rho \rho \mathrm{m}$ & - & Tidak ada \\
\hline
\end{tabular}

Tabel 1 menunjukkan hasil uji resisten merkuri dengan menggunakan media Luria Bertani (LB) Broth yang berisi $\mathrm{HgCl}_{2}$ dengan konsentrasi berbeda. Pada konsen- trasi $\mathrm{HgCl}_{2} 10$ ppm terdapat pertumbuhan bakteri dengan jumlah banyak dan pertumbuhan bakteri masih cepat. Pada konsentrasi $\mathrm{HgCl}_{2} 20 \mathrm{ppm}$ pertumbuhan bakteri dengan jumlah sedang, pertumbuhan bakteri sudah lambat. Pada konsentrasi $\mathrm{HgCl}_{2} 40$ ppm masih terdapat pertumbuhan bakteri tetapi sedikit, sedangkan pada konsentrasi $\mathrm{HgCl}_{2} 80$ ppm tidak terdapat pertumbuhan bakteri atau mati.

Tabel 2. Uji Resistensi Antibiotik Amoksisilin

\begin{tabular}{ccc}
\hline $\begin{array}{c}\text { Pengulangan } \\
\text { Pemberian } \\
\text { Antibiotik } \\
\text { Amoksisilin }\end{array}$ & $\begin{array}{c}\text { Zona } \\
\text { Hambat }\end{array}$ & Keterangan \\
\hline I & $7 \mathrm{~mm}$ & $\begin{array}{c}\text { Resisten } \\
\text { II }\end{array}$ \\
III & $7 \mathrm{~mm}$ & $\begin{array}{c}\text { Resisten } \\
\text { Resisten } \\
\text { Pseudomonas sp } \\
\text { resisten terhadap } \\
\text { amoksisilin }\end{array}$ \\
\hline
\end{tabular}

Tabel 2 menunjukkan hasil uji resistensi bakteri Pseudomonas sp terhadap antibiotik amoksisilin. Pengulangan pemberian antibiotik sebanyak 3 kali. Pada pemberian pertama diameter zona hambat Pseudomonas sp terhadap antibiotik Amoksisilin sebesar $7 \mathrm{~mm}$. Pada pengulangan kedua diameter zona hambat sebesar $7 \mathrm{~mm}$, dan pada pengulangan ketiga juga didapatkan hasil yang sama yaitu sebesar $7 \mathrm{~mm}$. Berdasarkan hasil yang didapatkan dari ketiga pengulangan tersebut, bakteri Pseudomonas sp resisten terhadap antibiotik amoksisilin.

\section{BAHASAN \\ Uji Resistensi Merkuri}

Bakteri adalah organisme bersel tunggal yang hidup bebas dan mampu bereproduksi sendiri. Bakteri tidak memiliki inti sel, terdiri atas sitoplasma yang dikelilingi oleh dinding sel yang terbuat dari suatu zat khusus yang disebut peptidoglikan. ${ }^{13}$ Suatu bakteri digolongkan bakteri resisten merkuri bila bertahan pada konsentrasi merkuri 10 ppm atau lebih. ${ }^{14}$

Uji resistensi merkuri diawali dengan 
mengambil bakteri Pseudomonas sp pada plak gigi pasien dengan tambatan amalgam merkuri, kemudian menumbuhkan bakteri tersebut ke dalam media LB Broth dengan menggunakan konsentrasi merkuri $\left(\mathrm{HgCl}_{2}\right)$ yang berbeda yaitu 10 ppm, 20 ppm 40 ppm, dan 80 ppm. Hal ini bertujuan untuk melihat konsentrasi merkuri dengan kemampuan bakteri dapat tumbuh.

Tabel 1 menunjukkan bahwa pada konsentrasi $\mathrm{HgCl}_{2} 10$ ppm bakteri tumbuh dengan baik dan pertumbuhannya lebih cepat dibandingkan dengan konsentrasi $\mathrm{HgCl}_{2} 20$ ppm. Begitu juga konsentrasi $\mathrm{HgCl}_{2} 20 \mathrm{ppm}$ pertumbuhannya lebih cepat dibandingkan dengan konsentrasi $\mathrm{HgCl}_{2} 40$ ppm. Pada konsentrasi 40 ppm masih terdapat pertumbuhan bakteri tetapi sedikit, sedangkan konsentrasi 80 ppm sudah tidak terdapat pertumbuhan.

Smith et al (1998) menambahkan bahwa perbedaan resistensi ini berhubungan dengan mekanisme respon populasi bakteri terhadap merkuri. Ada tiga mekanisme respon terhadap stres merkuri. Pertama, dengan cara menghambat metabolisme sel sehingga pertumbuhan sel lambat atau sel mati. Kedua, menginduksi sistem operon resisten merkuri untuk bekerja sehingga sel tetap hidup dalam kondisi stres. Ketiga, adanya plasmid yang mengandung gen resisten merkuri yang masuk ke dalam sel. ${ }^{8}$

Suhu dan $\mathrm{pH}$ merupakan faktor lingkungan yang sangat menentukan kehidupan bakteri. Suhu rendah dapat menyebabkan aktifitas enzim menurun dan jika suhu terlalu tinggi dapat mendenaturasi protein enzim. Pada suhu optimum pertumbuhan bakteri berlangsung dengan cepat. Di luar kisaran suhu optimum pertumbuhan bakteri menjadi lambat atau tidak ada pertumbuhan. ${ }^{14}$

\section{Uji Resistensi Antibiotik Amoksisilin}

Bakteri Pseudomonas sp dilakukan uji resistensi terhadap antibiotika amoksisilin. Antibiotika terpilih dalam uji tersebut pada dasarnya merupakan antibiotik yang sudah sangat umum digunakan. Dalam penelitian ini, uji resistensi antibiotik dilakukan dengan menggunakan media Luria Bertani (LB) broth padat.

Bakteri Pseudomonas sp resisten merkuri yang telah tumbuh dipindahkan ke dalam media LB padat dengan menggunakan metode gores. Kertas antibiotik (cakram) diletakkan menurut standar kedokteran yaitu Amoksisilin $25 \mu \mathrm{g}$.

Pada Tabel 2, dalam 3 kali pengulangan antibiotik didapatkan diameter zona hambat sebesar $7 \mathrm{~mm}$. Hal ini menunjukkan isolat bakteri Pseudomonas $s p$ resisten terhadap amoksisilin. Resistensi tersebut diketahui karena antibiotika amoksisilin tidak mampu menghambat pertumbuhan bakteri, sehingga zona hambatan yang terbentuk di bawah batasan resistensi.

Hasil penelitian ini sesuai dengan penelitian Refdanita et al. yang meneliti pendahuluan pola kepekaan kuman terhadap antibiotika di ruang rawat intensif Rumah Sakit Fatmawati Jakarta. Hasil menunjukkan salah satu kuman patogen yaitu Pseudomonas $s p$ dengan tingkat resistensi tinggi terhadap amoksisilin. ${ }^{15}$

Penelitian oleh Hariyadi di Fakultas Farmasi Universitas Ahmad Dahlan Yogyakarta mennggunakan sampel urin penderita ISK. Salah satu bakteri penyebab ISK yaitu Pseudomonas sp. Media McConkey digunakan dalam penelitian. Uji kepekaan bakteri menggunakan metode difusi padat dengan disk antibiotika dan ditemukan bahwa Pseudomonas sp telah resisten terhadap amoksisilin (80\%). ${ }^{16}$

Penelitian oleh Leslie di Fakultas Farmasi Universitas Setiabudi Surakarta juga mengungkapkan bahwa Pseudomonas $s p$ resisten terhadap amoksisilin (100\%). Sampel yang digunakan ialah urin pasien rawat inap di RSUD DR. Moewardi kemudian diisolasi pada media Pseudomonas Selektif Agar. Bakteri hasil isolasi selanjutnya diuji sensifitasnya terhadap amoksisilin, kotrimoksazol, Seftriakson, dan Siprofloksasin. ${ }^{17}$

Resistensi terjadi ketika bakteri berubah dalam satu atau lain hal yang menyebabkan turun atau hilangnya efektivitas obat, senyawa kimia atau bahan 
lainnya yang digunakan untuk mencegah atau mengobati infeksi. Bakteri yang mampu bertahan hidup dan berkembang biak, menimbulkan lebih banyak bahaya. ${ }^{18}$

Perubahan dalam resistensi bakteri terhadap suatu antibiotik dapat disebabkan oleh beberapa hal, seperti: 1) penggunaan antibiotik yang terlalu sering, tidak rasional, tidak adekuat, dan tidak didahului oleh uji sensitivitas, 2) terapi antibiotik yang lama, akan memudahkan timbulnya kolonisasi bakteri yang resisten antibiotik akibat mekanisme selective pressure, dan 3) perawatan inap yang cukup lama juga dapat memengaruhi peningkatan resistensi karena risiko untuk terinfeksi strain bakteri resisten makin tinggi. Penurunan persentase resistensi dapat diakibatkan oleh keberhasilan pengendalian infeksi dan pembatasan penggunaan antibiotik. ${ }^{19}$

\section{SIMPULAN}

Berdasarkan hasil penelitian dapat disimpulkan bahwa Pseudomonas sp yang diisolasi dari plak gigi pasien dengan tambatan amalgam telah resisten terhadap merkuri dengan konsentrasi 10 ppm, 20 ppm, dan 40 ppm sedangkan pada konsentrasi 80 ppm bakteri sudah tidak bertumbuh.

Pseudomonas sp juga telah resisten terhadap antibiotik Amoksisilin dengan diameter zona hambat kurang dari $12 \mathrm{~mm}$.

\section{SARAN}

Perlu dilakukan penelitian lebih lanjut mengenai antibiotik lain,

Para praktisi kedokteran hendaknya menggalakan penelitian untuk menemukan antibiotika baru yang lebih poten terhadap bakteri resisten.

\section{DAFTAR PUSTAKA}

1. Rustagi N, Singh R. Mercury and Health Care. Indian Journal of Occupational Medicine. 2010;14(2):45-8.

2. Minessota Department of Health. Frequently Asked Question: Mercury in its Liquid Form, 2014

3. Irwan S. Efek Toksik Merkuri Metalik (Hg0). [cited 2014 oct 7]. Available from: http:

//www.forumsains.com/artikel/143

4. ADA. Dental Amalgam. Update on safety concers. J ADA. [cited 2014 Oct 7]. Available from: http://www.ada.org/ /media/ADA/Member\%20Center/FIle s/safety.ashx

5. Alfian Z. Merkuri: Antara Manfaat dan Efek Penggunaannya bagi Kesehatan Manusia dan Lingkungan. Pidato pengukuhan guru besar. medan: Universitas Sumatera Utara, 2006.

6. Nofiani R, Gusrizal. Bakteri Resisten Merkuri Spectrum Sempit dari Daerah Bekas Penambangan Emas Tanpa Izin (peti) Mandor Kalimantan barat. Jurnal Natur Indonesia. 2004;6(2):67-74.

7. Rehman A, Ali A. Uptake of Mercury by a Bacterium, Pseudomonas sp. AN29, Isolated. From Industrial Effluentsand Its Potential Use in Wastewater Treatment. Iranian Journal of Science \& Technology. 2014.38A3:231-7.

8. Ririn DA. Isolasi dan Uji Resistensi Antibiotik Bakteri Resistensi Merkuri (Hg) dari kawasan pantai Losari Makassar. Makassar: Jurusan Biologi FMIPA Universitas Hasanuddin, 2013; p. 1.

9. Marlina, Almasdy D, Aufa I. Deteksi Gen ctx pada Bakteri Vibrio cholerae Isolat Limbah Cair Rumah Sakit dan Uji Resistensinya Terhadap Beberapa Antibiotik. Padang: Jurusan Farmasi FMIPA Universitas Andalas, 2007.

10.Saptarini N, Rusniyanti. Evaluation of Content And Dissolution Profile Of Generic Amoxicillin Tablets Marketed In Indonesia. International Research Journal of Pharmacy. 2012;3(12):64-6.

11. Mulyana Y. Sensitivitas Sallmonella Sp. Penyebab Demam Tifoid Terhadap Beberapa Antibiotik Di Rumah Sakit Immanuel Bandung. Bandung: Bagian Mikrobiologi Fakultas Kedokteran Universitas Padjadjaran, 2009; p. 41.

12.Saiful B. Efektifitas Klinik Amoksisilin Pada Infeksi Akut Saluran Nafas Atas Untuk Menurunkan Kejadian Otitis Media Akut. [Cited 2014 Nov 27]. Available from: http://eprints.undip.ac.id/14146/1/1998 FK437.pdf

13.Corwin, Elizabeth J. Buku Saku Patofisiologi. Jakarta: EGC, 2009 
14.Mogi KT, Kepel B, Bodhi W. Bakteri Resisten Merkuri (Hg) pada Plak Gigi Pasien dengan Tumpatan Amalgam di Puskesmas Bahu. eBM. 2013;1(1).

15.Refdanita, Maksum R, Nurgani A, ndang P. Pola Kepekaan Kuman Terhadap Antibiotika Di Ruang Gawat Intensif Rumah Sakit Fatmawati Jakarta tahun 2001-2002. Makara Kesehatan. 2014;8(2):41-8.

16.Hariyadi S. Uji Resistensi Pseudomonas sp dari Urin Penderita Infeksi Saluran Kemih di Poli Penyakit Dalam Di RSU PKU Muhammadiyah Yogyakarta Terhadap Beberapa Antibiotika [Skripsi]. Yogyakarta: Fakultas Farmasi Universitas Ahmad Dahlan, 2007.
17.Leslie V. Uji Sensitivitas Antibiotik Amoksisilin, Kotrimoksazol, Seftriakson, dan Siprofloksasin terhadap Pesudomonas sp. Hasil Isolasi urin Pasien Rawat Inap di RSUD Dr. Moewardi Bulan Maret-April Tahun 2013 [Skripsi]. Surakarta: Fakultas Farmasi, Universitas Setia Budi, 2013.

18.Utami E. Antibiotika, Resistensi, dan Rasionalitas Terapi. Sainstis. 2012;1:124-38.

19.Firizki F. Pola kepekaan Eschericia Coli dan Klebsiella sp. terhadap antibiotik Sefalosporin periode tahun 2008-2012 di Bandar Lampung. Lampung: Fakultas Kedokteran Universitas Lampung, 2013. ISSN 2337-3776. 